\title{
Econometric assessment of the impact of drought on Murray-Darling Basin irrigation
}

\author{
J. D. Connor \\ CSIRO Sustainable Ecosystems, \\ Natural Resource Economics and Decision Science Group, Australia
}

\begin{abstract}
This paper provides an econometric assessment of how less water supply, and hotter and drier than normal weather in the recent Millennium Drought (19992010) impact irrigated area, irrigation water application rates, and irrigation revenues in the Murray-Darling Basin.

Keywords: irrigation, drought, economics, Murray-Darling Basin, econometrics.
\end{abstract}

\section{Introduction}

A growing and increasingly affluent world population is driving increasing food demand from the planet's finite food resources. Irrigation is seen by many as one of the approaches to realising increased food production. However, many of the world's major irrigation areas are arid and semiarid regions where the climate change prognosis is for hotter and drier weather with potential to reduce water available for irrigation [1]. The degree to which reduced water supply will impact irrigated food production depends on the ability of irrigators to adapt, improve efficiency of water use and substitute other factors of production for increasingly scarce water.

This chapter describes an assessment of irrigated agricultural sector impacts of a recent all time record drought, in one of the world's major irrigation basins, the Murray-Darling. We econometrically assess how changes over the drought in irrigated land area, yields per hectare and irrigation application rates per hectare can be explained by changes in irrigation water supply, changes in non-irrigation crop available water and crop prices. 


\section{Model description}

The modelling approach is econometric simulation. We estimated the area irrigated, gross value of irrigated agricultural production and water use per hectare in seventeen Australian Bureau of Statistics (ABS) natural resource management (NRM) regions within the Murray-Darling Basin (Figure 1) for years $2005 / 06$ to $2008 / 09$. Ten major commodities representing more than $95 \%$ of the value of basin production are included in the analysis.

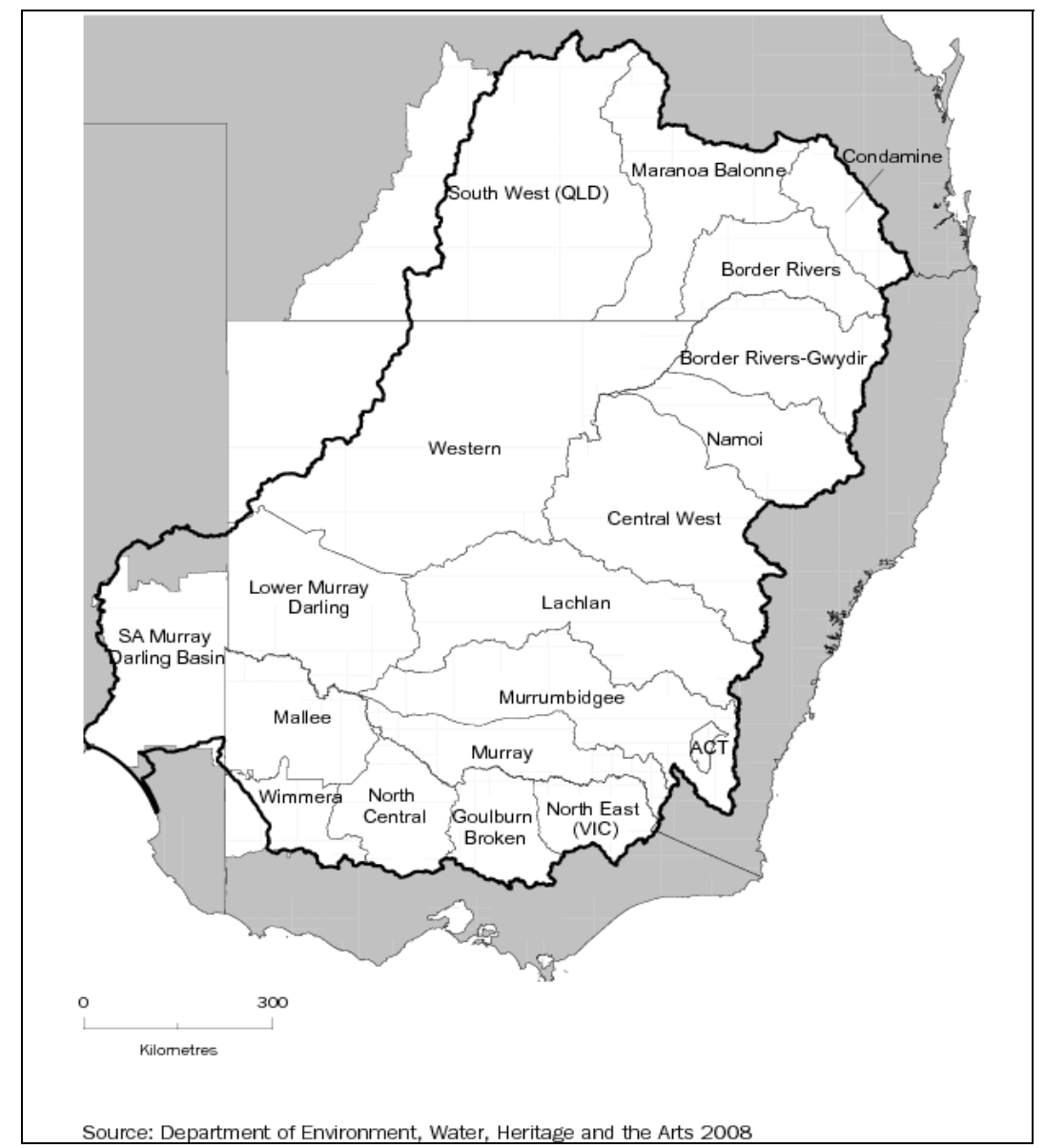

Figure 1: Murray-Darling Basin NRMs.

Explanatory variables included in area and irrigation application rate regressions were: water available for irrigation, annual evapotranspiration net of rainfall (a measure of non-irrigation water available for crop production), and crop prices. The estimated area was an additional variable in revenue equations. The variable definitions for all three regressions are summarised in Table 1. 
Table 1: $\quad$ Regression dependent and explanatory variables.

\begin{tabular}{|c|c|c|}
\hline Name & Description & Units \\
\hline \multicolumn{3}{|c|}{ Dependent variables } \\
\hline$A_{i, j, y}$ & Logits of land area (see equation (4)) & Logits \\
\hline$W_{i, j, y}$ & Irrigation application rate per hectare & $\mathrm{ML} / \mathrm{Ha}$ \\
\hline$R_{i, j, y}$ & Revenues from irrigated agricultural production & AU\$*10 $10^{6}$ \\
\hline \multicolumn{3}{|c|}{ Explanatory variables } \\
\hline$w a_{j, y}$ & $\begin{array}{l}\text { Regional irrigation water allocation measured as } \\
\text { the reported percentage of full regional entitlement } \\
\text { (ALLOCATION) }\end{array}$ & $\%$ \\
\hline$p_{i, y}$ & Commodity price (OWN PRICE) & \$/tonne \\
\hline$c_{i, j, y}$ & $\begin{array}{l}\text { Variable measuring climatic influence on crop } \\
\text { irrigation requirement calculated as crop potential } \\
\text { evapo-transpiration less crop available rainfall } \\
\text { (DNET) }\end{array}$ & $\mathrm{Mm}$ \\
\hline$n_{j}$ & $\begin{array}{l}\text { Binary indicator variable, equals one for regions in } \\
\text { the Darling and Lachlan catchments in the north of } \\
\text { the basin and zero for other regions. (NORTH) }\end{array}$ & Binary \\
\hline$P A_{i, j, y}$ & $\begin{array}{l}\text { Predicted land areas - result of regressions in } \\
\text { equation }(4) \text { - used as an explanatory variable in } \\
\text { revenue regressions. }\end{array}$ & $\mathrm{Ha}$ \\
\hline
\end{tabular}

Because the minimum level of land that can be allocated to any crop is 0 , a logistical functional form is chosen for the regression analysis. It is assumed that potential area is bounded by zero as a lower bound. For perennial and vegetable crops we assume that $95 \%$ of the maximum area observed between 2005/06 and $2008 / 09$ is an upper bound. For annual crops, the basin record suggests maximum irrigated area can be significantly larger than that observed in our four year time series, so we assume the maximum in the 114 year hydrologic time series in Kirby et al. [2]. The logits of the observed area in each year as a proportion of the maximum area for each crop are the dependent variable, $A_{i}$ in regression (equation (1)) where $\operatorname{area}_{i, j, y}$ is the area of crop $i$ for region $j$ observed in year $y$.

$$
\left.A_{i, j, y}=\log \left[\cdots\left(\operatorname{area}_{i, j, y} / \max \left(\operatorname{area}_{i, j, y}\right)\right) \cdots / \cdots\left(1 /\left(\operatorname{area}_{i, j, y}\right) / \max \left(\operatorname{area}_{i, j, y}\right)\right)\right) \cdots\right]
$$

Equation (2) is the regression model used to explain changes in irrigation area by crop.

$$
A_{i, j, y}=\alpha_{i}^{0}+\alpha_{i}^{w a} * w a_{i, j, y}+\alpha_{i}^{p} * p_{i, y}+\alpha_{i}^{c} * c_{i, j, y}+\alpha_{i}^{n} * n_{j}+e_{i, j, y}
$$


where the $\alpha$ s are the regression coefficients and the explanatory variables are explained in Table 1. Results of the regressions can be used to predict the areas by crop as a proportion of maximum potential area, $\mathrm{PA}_{\mathrm{i}}$ with equation (3).

$$
P A_{i, j, y}=\exp \left(\bar{A}_{i, j}, y\right) / \exp \left(1+\bar{A}_{i, j}, y\right)
$$

We estimated water use per hectare equations for each crop i, with the equation:

$$
W_{i, j, y}=\beta_{i}^{0}+\beta_{i}^{w a} * w a_{i, j, y}+\beta_{i}^{p} * p_{i, y}+\beta_{i}^{c} * c_{i, j, y}+\beta_{i}^{n} * n_{j}+e_{i, j, y}
$$

The explanatory variables are explained in Table 1 and the $\beta$ s are the regression coefficients. Area and water use equations applied to crops as opposed to livestock commodities of which there are seven: cereal (in which we include other broadacre crops such as barley); cotton; rice; pasture and hay (treated as one crop); wine, fruit and nuts (perennial horticulture); and vegetables.

The revenues (gross value of irrigated production, GVIAP in the terminology used by the Australian Bureau of Statistics were estimated with equation (5).

$$
R_{i, j, y}=\varphi_{i}^{0}+\varphi_{i}^{w a} * P A_{i, j, y}+\varphi_{i}^{p} * p_{i, y}+\varphi_{i}^{c} * c_{i, j, y}+\varphi_{i}^{n} * n_{j}+e_{i, j, y}
$$

This equation was estimated for the seven crop commodities: pasture, wheat, rice, cotton, horticulture, wine, and vegetables; and for three livestock commodities: beef, sheep, and dairy. For the all livestock revenue regressions, area of pasture is treated as the area explanatory: this is a proxy as data on separate areas available dedicated to each livestock commodity was not available.

\section{Data}

Irrigated area and water use per hectare by crop and NRM region data was sourced from the ABS catalogue 46180 series, Water Use on Australian Farmshttp://www.abs.gov.au/ausstats/abs@.nsf/mf/4618.0; GVIAP data was sourced from catalogue 46100, Experimental Estimates of the Gross Value of Irrigated Agricultural Production - http://www.abs.gov.au/ausstats/abs@.nsf/mf/4610. 0.55 .008 .

Time series gridded rainfall and area potential evapotranspiration (APET) derived from SILO datasets was obtained from Catchment Water Yield Estimation Tools (CWYET) project [3, 4] Under this project daily meteorological data from 1-Jan-1889 to 31-Aug-2009 collected by Bureau of Meteorology was interpolated at 0.05 x 0.05 degree cell across Australia [5]. Then daily gridded rainfall and APET was processed to calculate monthly rainfall and spatial average APET for 58 major sub-catchments in the MurrayDarling Basin. These sub-catchments are aggregates of the rainfall-runoff sub- 
catchments used in the Murray-Darling Basin. Water allocations data was sourced from the various volumes of Water Audit Monitoring Report: Report of the Murray Darling Basin Commission on the Cap on Diversions - available from the $M D B C$ prior to 2008/09 http://www2.mdbc.gov.au/_data/pagel 1782/MDBC_WAM_2006-07.pdf and from the MDBA from the 2008/09 season www.mdba.gov.au/water/river_info.

\section{Results}

Results of irrigated area regressions are shown in Table $2 . \mathrm{R}^{2}$ statistics $(0.34$ to 0.92) are reasonable for panel data but less satisfactory for perennial and vegetable crops: 0.10 (horticulture) to 0.22 (vegetables). Consistent with expectation, the signs on the coefficients for the allocation explanatory variable are positive for all area regressions, and in five cases they are statistically significant at p-values of 0.1 or less. The results lead us to conclude that that irrigated area declines with reductions in irrigation water supply for most crops. Our climatic variable (net ET less rain) and our price variables were statistically significant determinants of area change, all had p-values $>0.1$.

Table 2: $\quad$ Irrigated area by crop regression results.

\begin{tabular}{|c|c|c|c|c|c|c|}
\hline Crop & R-square & explanatory variable & coef & std & t-stat & $p$-value \\
\hline \multirow[t]{4}{*}{ Rice } & 0.92 & ALLOCATION & 10.002 & 2.375 & 4.211 & $\overline{0.014}$ \\
\hline & & DNET & 6.0413 & 5.972 & 1.012 & 0.369 \\
\hline & & OWN PRICE & 0.51971 & 1.726 & 0.3011 & 0.778 \\
\hline & & CONSTANT & -7.7986 & 3.262 & -2.391 & 0.075 \\
\hline \multirow[t]{4}{*}{ Cotton } & 0.34 & ALLOCATION & 2.8508 & 1.141 & 2.498 & 0.02 \\
\hline & & DNET & 0.56296 & 1.956 & 0.2878 & 0.776 \\
\hline & & PRICE & 2.0169 & 1.221 & 1.652 & 0.112 \\
\hline & & CONSTANT & -4.3236 & 1.145 & -3.778 & 0.001 \\
\hline \multirow[t]{4}{*}{ Cereal } & 0.51 & ALLOCATION & 3.7457 & 1.004 & 3.732 & 0.001 \\
\hline & & DNET & 0.12588 & 1.975 & $6.37 \mathrm{E}-02$ & 0.949 \\
\hline & & OWN PRICE & 0.0021 & 0.0035 & 0.5866 & 0.56 \\
\hline & & CONSTANT & -3.3302 & 1.272 & -2.617 & 0.012 \\
\hline \multirow[t]{4}{*}{ Wine } & 0.14 & ALLOCATION & 1.1335 & 0.5324 & 2.129 & 0.041 \\
\hline & & DNET & 0.249 & 0.5457 & 0.4558 & 0.651 \\
\hline & & OWN PRICE & -0.1927 & 0.5964 & -0.323 & $0.749-0.056$ \\
\hline & & CONSTANT & 1.6139 & 0.7149 & 2.258 & 0.031 \\
\hline \multirow[t]{4}{*}{ Horticulture } & 0.1 & ALLOCATION & 0.78932 & 0.6247 & 1.264 & 0.215 \\
\hline & & DNET & 1.9179 & 1.229 & 1.56 & 0.128 \\
\hline & & OWN PRICE & 0.21494 & 1.547 & 0.1389 & 0.89 \\
\hline & & CONSTANT & 1.073 & 1.716 & 0.6252 & 0.536 \\
\hline \multirow[t]{4}{*}{ Vegetables } & 0.22 & ALLOCATION & 1.3728 & 0.8196 & 1.675 & 0.104 \\
\hline & & DNET & -1.9769 & 1.611 & -1.227 & 0.229 \\
\hline & & OWN PRICE & -1.7982 & 2.008 & -0.8956 & 0.377 \\
\hline & & CONSTANT & 2.8374 & 2.224 & 1.276 & 0.211 \\
\hline \multirow[t]{5}{*}{ Pasture } & 0.66 & ALLOCATION & 3.226 & 0.6483 & 4.976 & 0 \\
\hline & & DNET & -1.4795 & 1.272 & -1.163 & 0.254 \\
\hline & & SUBSTITUTE PRICE* & -0.0021 & 0.002 & -1.048 & 0.303 \\
\hline & & CONSTANT & -1.0449 & 0.8733 & -1.197 & 0.241 \\
\hline & & NORTH & -0.109 & 0.3581 & -0.3044 & 0.763 \\
\hline
\end{tabular}


Irrigation application rate regression results are shown in Table 3. These regressions had relatively high R-squares for perennial (wine, horticulture) and vegetable crops (R-square 0.58 to 0.71 ) but more modest explanatory power for than annual crops (R-square 0.18 to 0.32 ). The annual crop rice was an exception with an r-square of 0.91 . Our measure of non-irrigation water availability (potential crop evapotranspiration net of rainfall) was a consistently significant determinant of water application rates. For six of the eight crops considered, higher values of this measure were positive and statistically significant determinants of variation in irrigation application rate. In contrast we did not find irrigation water availability level to be a statistically significant determinant of per hectare irrigation application rate for crops other than rice. Price variation was also not generally a statistically significant determinant of irrigation application rate. Exceptions were rice where price was a positive and significant determinant of irrigation rate; and pasture where the substitute commodity price (wheat) was found to be inversely related to irrigation rate of pasture.

Table 3: $\quad$ Irrigation water application rate regression results.

\begin{tabular}{|c|c|c|c|c|c|c|}
\hline Crop & R-square & explanatory variable & coef & std & t-stat & $\mathrm{p}$-value \\
\hline \multirow[t]{4}{*}{ Rice } & 0.91 & PRICE & 0.25923 & 0.0519 & 4.993 & 0.004 \\
\hline & & ALLOCATION & 0.20022 & 0.0671 & 2.982 & 0.031 \\
\hline & & NET & -0.20637 & 0.2192 & -0.9417 & 0.39 \\
\hline & & CONSTANT & 0.77737 & 0.2782 & 2.795 & 0.038 \\
\hline \multirow[t]{4}{*}{ Cotton } & 0.21 & PRICE & 0.0252 & 0.2652 & 0.0949 & 0.925 \\
\hline & & ALLOCATION & -0.0035 & 0.1095 & -0.0324 & 0.974 \\
\hline & & NET & 0.34228 & 0.1727 & 1.982 & 0.062 \\
\hline & & CONSTANT & 0.52341 & 0.3991 & 1.311 & 0.205 \\
\hline \multirow[t]{4}{*}{ Wheat } & 0.31 & PRICE & -0.18664 & 0.1242 & -1.503 & 0.154 \\
\hline & & ALLOCATION & 0.11648 & 0.0792 & 1.471 & 0.162 \\
\hline & & NET & 0.62759 & 0.2121 & 2.959 & 0.01 \\
\hline & & CONSTANT & 0.39895 & 0.181 & 2.204 & 0.044 \\
\hline \multirow[t]{5}{*}{ Horticulture } & 0.69 & PRICE & -1.4795 & 1.575 & -0.9395 & 0.354 \\
\hline & & ALLOCATION & -0.68831 & 0.8432 & -0.8163 & 0.42 \\
\hline & & NET & 4.4054 & 1.012 & 4.353 & 0 \\
\hline & & NORTH & -3.6054 & 0.4666 & -7.728 & 0 \\
\hline & & CONSTANT & 3.1108 & 2.05 & 1.518 & 0.138 \\
\hline \multirow[t]{5}{*}{ Vegetable } & 0.58 & PRICE & 0.80156 & 1.23 & 0.6515 & 0.519 \\
\hline & & ALLOCATION & -0.31677 & 0.618 & -0.5126 & 0.611 \\
\hline & & NET & 4.2242 & 0.6308 & 6.697 & 0 \\
\hline & & CONSTANT & 0.16238 & 1.475 & 0.1101 & 0.913 \\
\hline & & NORTH & -1.9296 & 0.3444 & -5.603 & 0 \\
\hline \multirow[t]{5}{*}{ Wine } & 0.71 & PRICE & -0.48285 & 0.4387 & -1.101 & 0.278 \\
\hline & & ALLOCATION & 0.73344 & 0.6103 & 1.202 & 0.237 \\
\hline & & NET & 6.0464 & 0.7076 & 8.545 & 0 \\
\hline & & CONSTANT & -1.9126 & 0.6778 & -2.822 & 0.008 \\
\hline & & NORTH & -1.9812 & 0.4323 & -4.583 & 0 \\
\hline \multirow[t]{5}{*}{ Pasture } & 0.18 & SUBST. PRICE & -0.79455 & 0.439 & -1.81 & 0.076 \\
\hline & & ALLOCATION & 0.2482 & 0.5028 & 0.4936 & 0.624 \\
\hline & & DNET & 1.2128 & 0.5091 & 2.382 & 0.021 \\
\hline & & NORTH & -0.37585 & 0.3048 & -1.233 & 0.223 \\
\hline & & CONSTANT & 3.5938 & 0.6151 & 5.842 & 0 \\
\hline
\end{tabular}


Revenue regression results are shown in Table 4. Explanatory power of the crop revenue regressions were very good (R-squares from 0.51 to 0.99 ) the regression also a reasonably good explanatory power for livestock commodities and pasture (R-squares from 0.37 to 0.62 ).

Table 4: $\quad$ Revenue regression results.

\begin{tabular}{|c|c|c|c|c|c|c|}
\hline Crop & R-square & explanatory variable & coef & Std & t-stat & p-value \\
\hline \multirow[t]{4}{*}{ Wheat } & 0.86 & PRICE & 0.0128 & 0.018 & 0.7105 & 0.481 \\
\hline & & AREA & 0.0008 & 0.0001 & 15.57 & 0 \\
\hline & & DNET & -17.436 & 10.33 & -1.688 & 0.098 \\
\hline & & CONSTANT & -0.93659 & 5.568 & -0.1682 & 0.867 \\
\hline \multirow[t]{4}{*}{ Rice } & 0.99 & PRICE & 74.539 & 6.221 & 11.98 & 0.053 \\
\hline & & AREA & 0.0047 & 0.0001 & 39.46 & 0.016 \\
\hline & & DNET & 186.4 & 18.38 & 10.14 & 0.063 \\
\hline & & CONSTANT & -126.52 & 10.53 & -12.02 & 0.053 \\
\hline \multirow[t]{4}{*}{ Cotton } & 0.79 & PRICE & 218.22 & 190.8 & 1.144 & 0.296 \\
\hline & & AREA & 0.0104 & 0.0024 & 4.238 & 0.005 \\
\hline & & NET & -187.86 & 149.2 & -1.259 & 0.255 \\
\hline & & CONSTANT & -24.149 & 263.1 & -0.0918 & 0.93 \\
\hline \multirow[t]{5}{*}{ Pasture } & 0.63 & PRICE & 0.0049 & 0.0209 & 0.2366 & 0.815 \\
\hline & & AREA & 0.0001 & 0 & 3.658 & 0.001 \\
\hline & & DNET & 52.739 & 11.77 & 4.48 & 0 \\
\hline & & NORTH & 5.4882 & 2.564 & 2.14 & 0.041 \\
\hline & & CONSTANT & -1.3687 & 6.476 & -0.2113 & 0.834 \\
\hline \multirow[t]{4}{*}{ Vegetable } & 0.75 & PRICE & 138.06 & 71.22 & 1.938 & 0.066 \\
\hline & & AREA & 0.027 & 0.0046 & 5.85 & 0 \\
\hline & & DNET & 57.458 & 49.54 & 1.16 & 0.259 \\
\hline & & CONSTANT & -167 & 81.99 & -2.037 & 0.054 \\
\hline \multirow[t]{5}{*}{ Horticulture } & 0.51 & PRICE & 86.768 & 138.1 & 0.6282 & 0.538 \\
\hline & & AREA & 0.011 & 0.0042 & 2.63 & 0.017 \\
\hline & & NET & -131.63 & 106.6 & -1.235 & 0.233 \\
\hline & & NORTH & -6.6332 & 38.2 & -0.1736 & 0.864 \\
\hline & & CONSTANT & 76.128 & 209.9 & 0.3627 & 0.721 \\
\hline \multirow[t]{5}{*}{ Grapes } & 0.9 & PRICE & 105.26 & 40.71 & 2.585 & 0.023 \\
\hline & & AREA & 0.0072 & 0.0008 & 8.829 & 0 \\
\hline & & DNET & -5.7854 & 158 & -0.0366 & 0.971 \\
\hline & & NORTH & -0.0778 & 24.49 & -0.0032 & 0.998 \\
\hline & & CONSTANT & -111.64 & 46.13 & -2.42 & 0.031 \\
\hline \multirow[t]{4}{*}{ Beef } & 0.37 & PRICE & 194.25 & 103 & 1.886 & 0.073 \\
\hline & & AREA & 0.00016 & 0.00009 & 1.869 & 0.075 \\
\hline & & NET & -47.26 & 36.19 & -1.306 & 0.205 \\
\hline & & CONSTANT & -132.74 & 95.41 & -1.391 & 0.178 \\
\hline \multirow[t]{4}{*}{ Sheep } & 0.65 & PRICE & 848.91 & 1259 & 0.6745 & 0.505 \\
\hline & & AREA & 0.00014 & 0.00002 & 6.163 & 0 \\
\hline & & DNET & 17.237 & 9.829 & 1.754 & 0.09 \\
\hline & & CONSTANT & 1.9365 & 5.022 & 0.3856 & 0.703 \\
\hline \multirow[t]{5}{*}{ Dairy } & 0.62 & PRICE & 102.73 & 96.19 & 1.068 & 0.299 \\
\hline & & AREA & 0.00094 & 0.00029 & 3.213 & 0.005 \\
\hline & & DNET & 693.99 & 132.2 & 5.248 & 0 \\
\hline & & NORTH & -46.34 & 35.14 & -1.319 & 0.203 \\
\hline & & CONSTANT & -121.44 & 117.1 & -1.037 & 0.313 \\
\hline
\end{tabular}

The area was a positive and statistically significant determinant of revenue in all regressions. Commodity prices were also found to be positively related to 
revenue for all commodities considered. The relationship was statistically significant at $90 \%$ confidence or better ( $p$-value $<0.1$ ) for three of these ten regressions. We found our measure of non-irrigation water variation to be a significant determinant of revenue from wheat, rice, pasture dairy and sheep. For all crops other than rice, higher evaporation less rainfall (less non-irrigation water supply) was correlated with greater revenue.

\section{Discussion}

Drought has several impacts on irrigation: less rain and runoff result in less irrigation water availability; hotter weather and less rain result in greater crop water irrigation requirements. The regression results above show that for the Murray-Darling Basin a primary response to less available irrigation water was a contraction of the area irrigated, especially in annual crops. Regression also showed that irrigation application rates on land that stayed in production increased in many instances. This finding, along with the finding that for some commodities, revenues were positively related to hotter and drier weather, suggests that the hot dry weather during the drought, with increased irrigation rates may actually have led to increased yields of some irrigation crops.

One of the challenges with the regressions is that there are likely to have been adjustments in other factors of production, for example irrigation capital, but no data was available measuring capital and labour inputs. Potential extensions to this work could control for omitted variable impacts, for example with a fixed effects specification. There may also be opportunities to improve estimation efficiency through regression techniques that account for cross equation correlation.

\section{Conclusions}

We found that the cropped area was significantly influenced by water supply available for irrigation for all crops. Small but significant area changes in perennials and vegetables could be explained by changes by this variable. Moderate (cotton, pasture, cereal) to large (rice) changes in annual crop area also estimated in response to irrigation water supply changes observed over the sample. Both price level changes and changes in non-irrigation water supply could not be statistically significantly related to sample irrigated crop area change. Statistically significantly greater rates of irrigation application per hectare were found for greater non-irrigation water deficit for six of eight crops considered. Commodity price and irrigation supply level variation were mostly not found to be statistically significant determinant of irrigation application rates, except for rice. The most consistently significant determinant of estimated GVAIP across all commodities considered was estimated area of crop (or pasture for livestock commodities). 


\section{References}

[1] McCarthy, J., Canziani, O., Leary, N., Dokken, D. and White, K., Climate Change 2001: Impacts, Adaptation, and Vulnerability, Cambridge University Press: Cambridge, 2001.

[2] Kirby, M., Connor, J., Bark, R., Qureshi, E. \& Keyworth, S., The economic impact of water reductions during the Millennium Drought in the MurrayDarling Basin. $56^{\text {th }}$ Australian Agricultural and Resource Economics Society Annual Conference, Fremantle, 7-10 February, 2012.

[3] Vaze, J., Chiew, F.H.S., Perraud, J.M., Viney, N., Post, D.A., Teng, J., Wang, B., Lerat, J. and Goswami, M., Rainfall-runoff modelling across southeast Australia: datasets, models and results. Australian Journal of Water Resources, 14(2), pp. 101-116, 2011.

[4] Vaze, J., Perraud, J.M., Teng, J., Chiew, F.H.S., Wang, B. and Yang, Z., Catchment Water Yield Estimation Tools (CWYET). 34 ${ }^{\text {th }}$ International Association for Hydro-Environment Engineering and Research World Congress, Brisbane, 27 June - 1 July, 2011.

[5] Jeffrey, S.J., Carter, J.O., Moodie, K.B. and Beswick, A.R., Using spatial interpolation to construct a comprehensive archive of Australian climate data. Environmental Modelling \& Software, 16(4), pp. 309-330, 2001. 